\title{
PREPARATION AND INVESTIGATION OF THE PHOTOCATALYTIC PROPERTIES OF PERIWINKLE SHELL ASH FOR TARTRAZINE DECOLOURISATION
}

\author{
N.A. Amenaghawon ${ }^{1}$, J.O. Osarumwense ${ }^{2}$, F.A. Aisien ${ }^{1}$ and O.K. Olaniyan ${ }^{1}$ \\ ${ }^{1}$ Department of Chemical Engineering, Faculty of Engineering, University of Benin, \\ PMB 1154, Ugbowo, Benin City, Edo State, Nigeria \\ *Email: andrew.amenaghawon@uniben.edu \\ Phone: +2348069275563 \\ ${ }^{2}$ Department of Science Laboratory Technology, \\ Faculty of Life Sciences, University of Benin, \\ PMB 1154, Ugbowo, Benin City, Edo State, Nigeria
}

\begin{abstract}
The discharge of dye-containing effluents into the aquatic environment represents a source of aesthetic pollution with associated negative effects. Photocatalytic degradation has been identified as a suitable means of treating these effluents. In this study, the potential of a locally sourced material, periwinkle shell ash (PSA), has been explored as an effective photocatalyst for the photocatalytic decolourisation of tartrazine in aqueous solution. The efficiency of the photocatalyst was evaluated by investigating the effects of operational variables such as irradiation time, initial dye concentration and catalyst loading on the extent of decolourisation. The results show that the optimum levels of the variables were 50 minutes, $30 \mathrm{mg} / \mathrm{L}$ and $5 \mathrm{~g} / \mathrm{L}$ for irradiation time, initial dye concentration and catalyst loading respectively. The pseudo first order and the Langmuir-Hinshelwood kinetic models were able to sufficiently describe the kinetics of the process. The diffusion mechanism was described by the intra-particle diffusion model while the adsorption equilibrium was described by the Langmuir isotherm equation. The results obtained indicate that PSA can be used as an effective photocatalyst for the removal of tartrazine from aqueous solution.
\end{abstract}

Keywords: Periwinkle shell ash; tartrazine; kinetics; isotherm; equilibrium.

\section{INTRODUCTION}

Water pollution due to the discharge of coloured effluents from textile dye manufacturing and textile dye mills is one of the major environmental concerns in the world today [1]. It has been reported that between 1 and $20 \%$ of the dye is lost during the dyeing process and it is subsequently released in wastewater [2]. The release of these coloured wastewaters poses serious aesthetic and ecological problems such as eutrophication to the aquatic ecosystems [3]. Azo dyes are considered to be the largest group among the established classes of synthetic dyes and an important example is tartrazine. Tartrazine is a useful colorant widely employed in food products, drugs, cosmetics etc. Nevertheless, the toxic and harmful effects of tartrazine have been established by numerous studies [4-7]. Hence, these types of dyes have been classified as potentially carcinogenic and mutagenic by the US National Institution for Occupational Safety and Health [8]. Their chemical structures are characterised by 
highly substituted aromatic rings joined by one or more azo groups [9]. These substituted ring structures make the dye molecules recalcitrant and not readily amenable to degradation by conventional wastewater treatment methods [10].

Different physical, chemical and biological methods have been applied for the treatment of dye-containing effluents. Physical methods are not effective, they do not degrade the dye and the dyes are merely transferred to another phase, thereby introducing the need for further treatment steps [11]. Biological methods appear to be effective and economical. However, this treatment does not lead to the mineralisation of the dyes as they are only adsorbed on the sludge [3]. Heterogeneous photocatalytic degradation facilitated by semiconductor catalysts has been identified as a promising technique for the removal of most dyes from liquid effluents [10, 12]. The photocatalytic reaction takes place when the semiconductor particle absorbs a photon of light which is more energetic than its band gap, leading to the excitation of the electron from the valence band to the conduction band. A hole-electron pair is formed in the process and this initiates the oxidation of the dye [13]. The important advantage of this method is that it often results in complete mineralisation and degradation of most pollutants that are not amenable to other treatment processes [14]. Furthermore, it is cheaper than most processes and it can be carried out under ambient conditions [1]. Several studies have been carried out on photocatalytic degradation of dyes, mainly with $\mathrm{TiO}_{2} / \mathrm{UV}$ or $\mathrm{ZnO} / \mathrm{UV}$ systems, and these studies have established the factors that influence the rate of the photocatalytic reaction [15-20]. However, $\mathrm{TiO}_{2}$ has an important shortcoming in that it absorbs only a limited amount of photons in the UV region. Hence it requires a high power UV excitation source to function effectively [21]. Some researchers have reported the preparation of photocatalysts from waste materials [22-25]. However, very little work has been reported on the preparation of photocatalysts from periwinkle shells $[12,26,27]$. Hence the focus of this work is to evaluate the potential application of periwinkle shell ash as a photocatalyst for the photocatalytic decolourisation of tartrazine in aqueous solutions. The effects of operational variables such as irradiation time, initial dye concentration and catalyst loading on the decolourisation process were investigated. The photocatalytic decolourisation of tartrazine was further evaluated by carrying out kinetic (pseudo first order, pseudo second order, intra-particle diffusion and Langmuir-Hinshelwood models) and isotherm studies (Langmuir and Freundlich isotherms).

\section{MATERIALS AND METHODS}

\section{Preparation and Characterisation of Periwinkle Shell Ash}

Periwinkle shells were sourced locally from Benin City in Edo State of Nigeria. The shells were washed and dried in an oven at $110{ }^{\circ} \mathrm{C}$ to constant mass, followed by crushing and calcination at $600{ }^{\circ} \mathrm{C}$ in a muffle furnace and subsequent sieving to obtain fine particles $(<350 \mu \mathrm{m})$ of periwinkle shell ash (PSA). The prepared PSA was characterised by determining the composition using X-ray fluorescence (XRF) analysis. $\mathrm{X}$-ray diffraction (XRD) was used to determine the ultimate elemental composition of the PSA using a Philips X-ray diffractometer $[12,28]$. The functional groups on the PSA surface were determined by Fourier transform infrared spectrometry (FTIR) using a Perkin Elmer spectrum 100 FT-IR spectrometer in the frequency range 4000 to 400 $\mathrm{cm}^{-1}$, operating in ATR (attenuated total reflectance) mode. The surface structure and 
other properties of the PSA were evaluated by the nitrogen adsorption method at -196 ${ }^{\circ} \mathrm{C}$. The surface area of the PSA was determined using the standard BET equation.

Dye

All reagents and chemicals used in this study were of analytical grade and were used without further purification. Tartrazine dye with molecular formula $\mathrm{C}_{16} \mathrm{H}_{9} \mathrm{~N}_{4} \mathrm{Na}_{3} \mathrm{O}_{9} \mathrm{~S}_{2}$ and molecular weight $534.36 \mathrm{~g} / \mathrm{mol}$ was obtained from Stanvac Laboratories in Benin City, Edo State, Nigeria. The molecular structure of the dye is shown in Figure 1.<smiles>O=C(O[Na])c1nn(-c2ccc(S(=O)(=O)O[Na])cc2)c(O)c1/N=N/c1ccc(S(=O)(=O)[O-])cc1</smiles>

Figure 1. Chemical structure of tartrazine "trisodium 1-(4-sulfonatophenyl)-4-(4sulfonatophenylazo)-5-pyrazolone-3-carboxylate)" [8].

\section{Photoreactor}

The experimental set-up has been described previously [12]. The reactor was irradiated by four UV lamps emitting at $254 \mathrm{~nm}$ (40 W, Philips TUV G6T5). The intensity of the light emitted by the lamps was measured as $1.65 \mathrm{~mW} / \mathrm{cm}^{2}$ using a Lux-UV-IR meter (Leybold Co.).

\section{Photocatalytic Degradation Studies}

The dye solution was prepared in appropriate concentrations using deionised water. The photocatalytic decolourisation studies were conducted using $4000 \mathrm{~mL}$ of dye solution and a predetermined quantity of photocatalyst. With the UV lamps still off, air was bubbled at a predetermined flowrate through the dye solution in the holding tank. The lamps were subsequently turned on and the pump was started to convey the dye-catalyst suspension into the reactor. Samples of $25 \mathrm{~mL}$ aliquots were withdrawn at regular intervals and were immediately centrifuged at $8000 \mathrm{rpm}$ for $10 \mathrm{~min}$ to remove suspended catalyst particles. The progress of the photocatalytic decolourisation process was monitored by measuring the absorbance of the samples with a UV-Visible spectrophotometer (Shimadzu UV $2101 \mathrm{PC}$ ) at a wavelength of $520 \mathrm{~nm}$. A calibration curve based on Beer-Lambert's law was established by relating the absorbance to the concentration. The effect of irradiation time, initial dye concentration and photocatalyst loading on the decolourisation efficiency was then investigated. The percentage photocatalytic decolourisation of tartrazine dye was calculated using Eq. (1).

$$
\text { Decolourisation efficiency }=\frac{C_{o}-C_{t}}{C_{o}} \times 100
$$

The amounts of tartrazine adsorbed at time $t,\left(q_{t}\right)$ and at equilibrium $\left(q_{e}\right)$ were calculated using Eqs. (2)-(3).

$$
q_{t}=\frac{V_{s}\left(C_{o}-C_{t}\right)}{W}
$$




$$
q_{e}=\frac{V_{s}\left(C_{o}-C_{e}\right)}{W}
$$

where $C_{o}, C_{e}$ and $C_{t}$ are the initial, equilibrium and instantaneous concentrations of tartrazine respectively. $V_{s}$ is the volume of the aqueous solution and $W$ is the amount of catalyst.

\section{RESULTS AND DISCUSSION}

\section{Characterisation of Photocatalyst}

The results of the chemical composition analysis of the PSA have been previously reported $[12,26]$. The XRF results indicated that the major constituents of the PSA were calcium oxide $(\mathrm{CaO})$, silica $\left(\mathrm{SiO}_{2}\right)$ and aluminium oxide $\left(\mathrm{Al}_{2} \mathrm{O}_{3}\right)$, which respectively accounted for 41.3, 33.2 and $9.2 \%$ of the weight of PSA analysed. XRD results indicated that the major elements in PSA were iron $(\mathrm{Fe})$ and zinc $(\mathrm{Zn})$, which respectively accounted for 19.2 and $16.5 \%$ of the weight of PSA analysed. Other oxides and elements were also present but in small proportions. Navaladian et al. [29] reported that transition metals and their oxides are known to exhibit catalytic properties, thus supporting the choice of PSA for this study. Similar observations have been reported by other researchers $[18,30]$. The surface area, bulk density, and porosity of the PSA were similar to those reported in the literature [31, 32]. FTIR results revealed peaks of $3626.59 \mathrm{~cm}^{-1}, 1797.58 \mathrm{~cm}^{-1}, 1561.43 \mathrm{~cm}^{-1}$ and $1374.34 \mathrm{~cm}^{-1}$ in the infrared spectrum of periwinkle shell ash, corresponding to $\mathrm{O}-\mathrm{H}, \mathrm{C}=\mathrm{O}, \mathrm{C}=\mathrm{C}$ and $\mathrm{C}-\mathrm{H}$ bonds respectively. Absorption bands in the range of 2700 to $1430 \mathrm{~cm}^{-1}$ and 900 to $1380 \mathrm{~cm}^{-1}$ indicate the presence of phenyl groups and the stretching of the $\mathrm{C}-\mathrm{O}$ bond in carboxylic groups present in the PSA [33]. These FTIR bands represent functional groups that possess strong bonds which can be protonated in slightly acidic conditions to be potential adsorption sites for organic molecules [34].

\section{Effect of Irradiation Time}

Figure 2 shows the effect of irradiation time on the photocatalytic decolourisation of tartrazine by PSA. The decolourisation efficiency showed a steady and progressive increase with increase in irradiation time, to attain a maximum value of about $81 \%$ at an irradiation time of 50 minutes. Increasing the irradiation time beyond 50 minutes did not have any impact on the decolourisation process. The initial increase in the decolourisation efficiency could be attributed to the abundance of active sites on the surface of the photocatalyst, which favoured the photocatalytic reaction [35]. As the reaction proceeds further, these active sites are then occupied by several layers of dye molecules, such that the rate of the decolourisation reaction slows down. Furthermore, the insignificant change in the decolourisation efficiency observed beyond 50 minutes of irradiation time could also indicate that the system had attained a state of equilibrium, which means that the catalyst had become saturated and could no longer adsorb any more dye molecules [8]. Equilibrium times in the range of 90 to 120 minutes were reported by Chakrabarti and Dutta [36] under varying conditions of photocatalytic degradation of model textile dyes in wastewater using $\mathrm{ZnO}$ as photocatalyst. Akyol et al. [37] reported lower equilibrium times of 25 and 35 minutes respectively for the photocatalytic decolourisation of Remazol Red RR in aqueous systems using $\mathrm{ZnO}$ and 
$\mathrm{TiO}_{2}$ as photocatalysts. These results show that the photocatalytic decolourisation of dyes is a fast kinetic process.

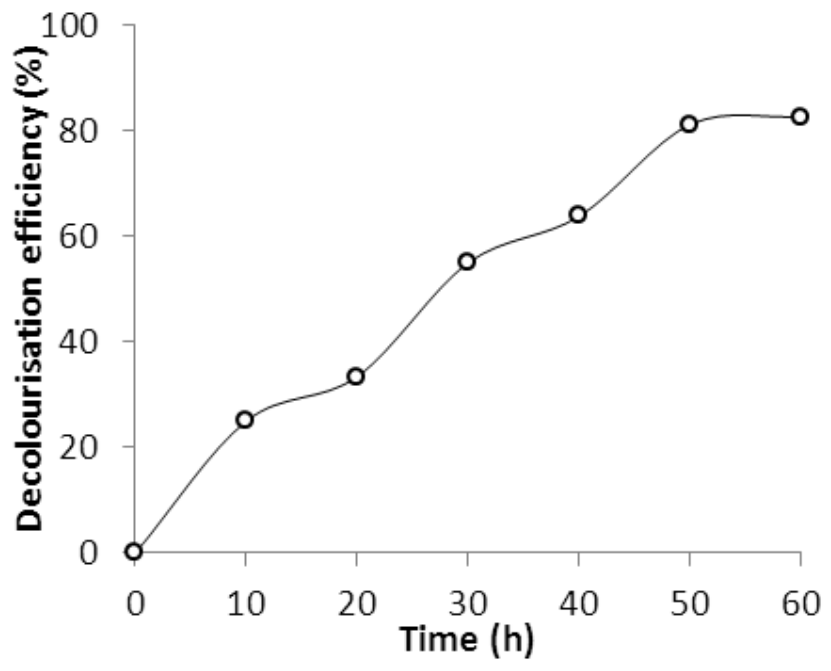

Figure 2. Effect of irradiation time on the photocatalytic decolourisation of tartrazine (PSA loading, $5 \mathrm{~g} / \mathrm{L}$; initial concentration, $30 \mathrm{mg} / \mathrm{L}$; temperature, $25^{\circ} \mathrm{C}$ ).

\section{Effect of Initial Dye Concentration}

The initial concentration of the dye solution influenced the decolourisation process as shown in Figure 3. The decolourisation efficiency initially increased from about $8 \%$ to about $83 \%$ when the initial dye concentration was increased from 10 to $30 \mathrm{mg} / \mathrm{L}$. Increasing the concentration of dye beyond $30 \mathrm{mg} / \mathrm{L}$ resulted in a decrease in the decolourisation efficiency. Konstantinou and Albanis [38] noted that the rate of dye degradation generally increases with the increase in dye concentration up to a certain level beyond which any further increase in dye concentration does not positively affect the degradation process. Similar observations have been reported by Sakthivel et al. [18]. The rate of the degradation reaction is dependent on the rate of formation of the hydroxyl radicals as well as the probability of the radicals reacting with the dye molecules. As the concentration of dye is increased, there will be more of the dye molecules in the solution and this will increase the probability of the radicals reacting with the dye molecules, consequently resulting in an enhancement of the rate of the degradation of the dye [38]. However, as the concentration of dye is increased beyond the optimum point, the decolourisation efficiency decreased because of the decrease in the formation of hydroxyl radicals on the surface of the catalyst. The reason for this could be that the active sites on the catalyst surface are occupied by layers of dye molecules $[39,40]$. Furthermore, at high concentrations of dye, a significant amount of the UV radiation could be absorbed by the dye molecules rather than the PSA particles and this reduces the efficiency of the decolourisation process because of the reduction in the rate of formation of the oxidising radicals [41]. 


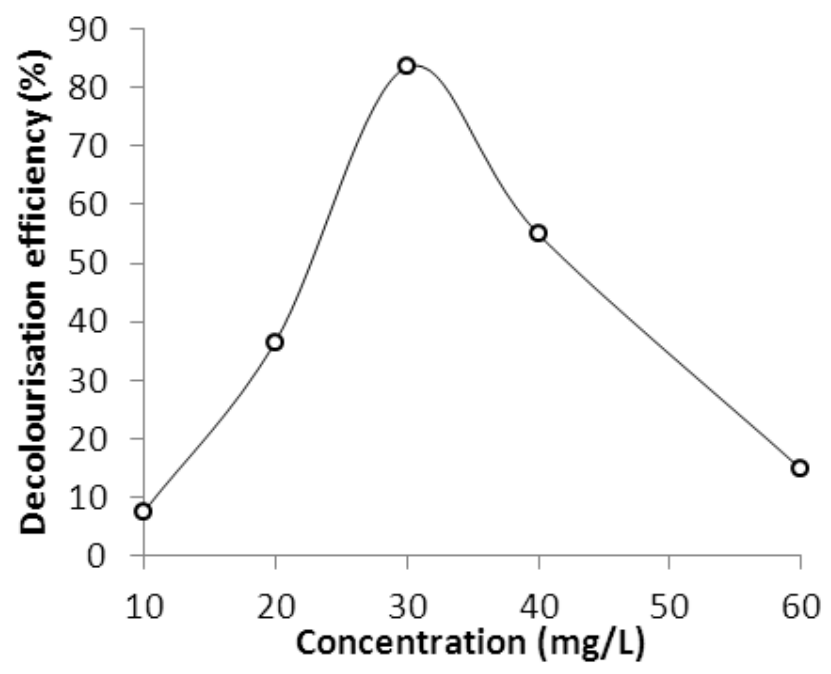

Figure 3. Effect of initial dye concentration on the hotocatalytic decolourisation of tartrazine (PSA loading, $5 \mathrm{~g} / \mathrm{L}$; temperature, $25^{\circ} \mathrm{C}$ ).

\section{Effect of Catalyst Loading}

Figure 4 shows the effect of PSA loading on the decolourisation efficiency. With increase in PSA loading from 1 to $5 \mathrm{~g} / \mathrm{L}$, the decolourisation efficiency increased from about 19 to $85 \%$. Further increase in PSA loading did not have any positive impact on the decolourisation process. The initial increase in decolourisation efficiency observed might be rationalised in terms of the availability of active sites on the PSA surface. The availability of active sites increases with increase in catalyst loading, and hence the rate of decolourisation is enhanced [15].

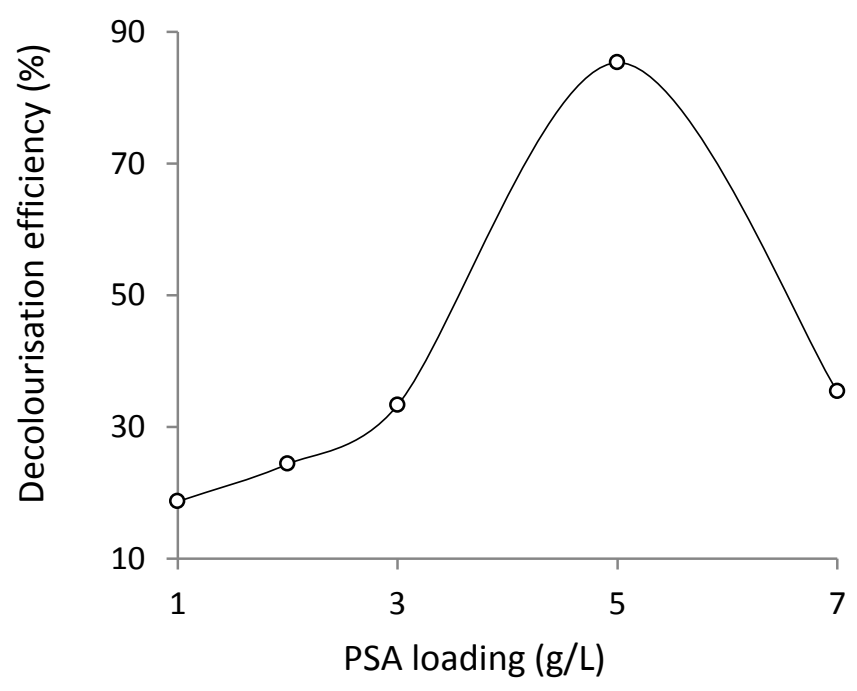

Figure 4. Effect of PSA loading on the photocatalytic decolourisation of tartrazine (initial concentration, $30 \mathrm{mg} / \mathrm{L}$; temperature, $25{ }^{\circ} \mathrm{C}$ ).

Inasmuch as elevated levels of catalyst loading increase the availability of active sites on the catalyst surface, they also lead to a reduction in the light penetration and consequently a reduction in the photoactivated volume of the suspension. This explains 
the decrease in decolourisation efficiency observed beyond a catalyst loading of $5 \mathrm{~g} / \mathrm{L}$. Some researchers have suggested that at high catalyst loading, agglomeration and sedimentation of the catalyst particles could occur, making a fraction of the catalyst surface unavailable for photon and dye absorption [42]. According to Suri et al. [43], the optimum catalyst dosage could be dependent on the initial solute concentration. They further suggested that it might not be advisable to use higher catalyst loadings as a result of possible aggregation and reduced irradiation field.

\section{Kinetics of Photodegradation}

For engineering purposes, it is important to determine a rate equation that fits the experimental data. Since adsorption is considered critical in the heterogeneous photocatalytic degradation process, the kinetics of the photodegradation process was studied using four kinetic models, namely pseudo first order, pseudo second order, intra-particle diffusion and Langmuir-Hinshelwood kinetic models. These models are elucidated in the following sections.

\section{Pseudo First Order Model}

The pseudo first order kinetic model is expressed in its integrated linear form as follows [44]:

$$
\ln \left(q_{e}-q_{t}\right)=\ln q_{e}-k_{1} t
$$

where $q_{e}$ and $q_{t}(\mathrm{mg} / \mathrm{g})$ are adsorption capacity at equilibrium and at time $t$ respectively. $k_{l}$ is the rate constant of pseudo first order adsorption $(1 / \mathrm{min})$. The values of $\ln \left(q_{e}-q_{t}\right)$ were plotted against $t$. The plot of $\ln \left(q_{e}-q_{t}\right)$ against $t$ resulted in a linear relationship from which the values of $k_{l}$ and $q_{e}$ were determined as shown in Figure 5. The values of the constants are given in Table 1. The linear relationship observed in Figure 5 suggests that the pseudo first order model was applicable to the process.

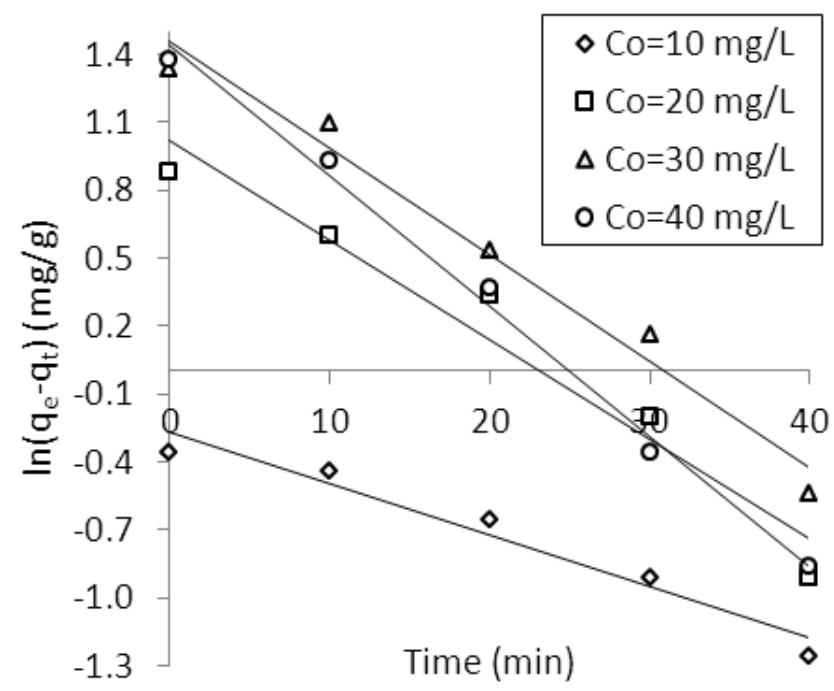

Figure 5. Pseudo first order model results for tartrazine photodegradation by PSA (PSA loading, $5 \mathrm{~g} / \mathrm{L}$; temperature, $25^{\circ} \mathrm{C}$ ). 
Table 1. Kinetic constant parameter values for the photocatalytic decolourisation of tartrazine.

\begin{tabular}{|c|c|c|c|c|c|c|c|c|c|c|c|}
\hline \multirow[t]{2}{*}{$\begin{array}{l}C_{o} \\
(\mathrm{mg} / \mathrm{L})\end{array}$} & \multicolumn{3}{|c|}{ Pseudo first order } & \multicolumn{3}{|c|}{$\begin{array}{l}\text { Pseudo second order } \\
\text { model }\end{array}$} & \multicolumn{3}{|c|}{$\begin{array}{l}\text { Intra-particle diffusion } \\
\text { model }\end{array}$} & \multicolumn{2}{|c|}{$\begin{array}{l}\text { Langmuir- } \\
\text { Hinshelwood } \\
\text { model }\end{array}$} \\
\hline & $k_{1}$ & $q_{e}$ & $R^{2}$ & $k_{2}$ & $q_{e}$ & $R^{2}$ & $K_{P}$ & $C$ & $R^{2}$ & & \\
\hline 10 & 0.023 & 0.76 & 0.958 & 0.024 & -0.49 & 0.846 & 0.05 & 0.0182 & 0.972 & $r$ & \\
\hline 20 & 0.044 & 2.76 & 0.950 & 0.00029 & -12.05 & 0.404 & 0.28 & 0.258 & 0.979 & $K$ & 0.0066 \\
\hline 30 & 0.047 & 4.28 & 0.976 & 0.00018 & 22.73 & 0.244 & 0.41 & 0.1905 & 0.984 & $R^{2}$ & 0960 \\
\hline 40 & 0.058 & 4.22 & 0.994 & 0.004 & 6.85 & 0.982 & 0.55 & 0.0791 & 0.991 & $x^{2}$ & 0.960 \\
\hline
\end{tabular}

\section{Pseudo Second Order Model}

The pseudo second order kinetic model is expressed in its integrated linear form as follows [45]:

$$
\frac{t}{q_{t}}=\frac{1}{k_{2} q_{e}^{2}}+\frac{1}{q_{e}} t
$$

$k_{2}$ is the rate constant of the pseudo second order process ( $\left.\mathrm{g} / \mathrm{mg} \cdot \mathrm{min}\right)$. The plot of $\left(\mathrm{t} / \mathrm{q}_{\mathrm{t}}\right)$ versus $t$ as shown in Figure 6 was used to calculate the values of the model parameters. The kinetic constants calculated from the plot at different initial dye concentrations are shown in Table 1. It is very obvious from Figure 6 that the pseudo second order model was not able to represent the kinetics of the degradation process, as seen in the very low $R^{2}$ values (Table 1$)$.

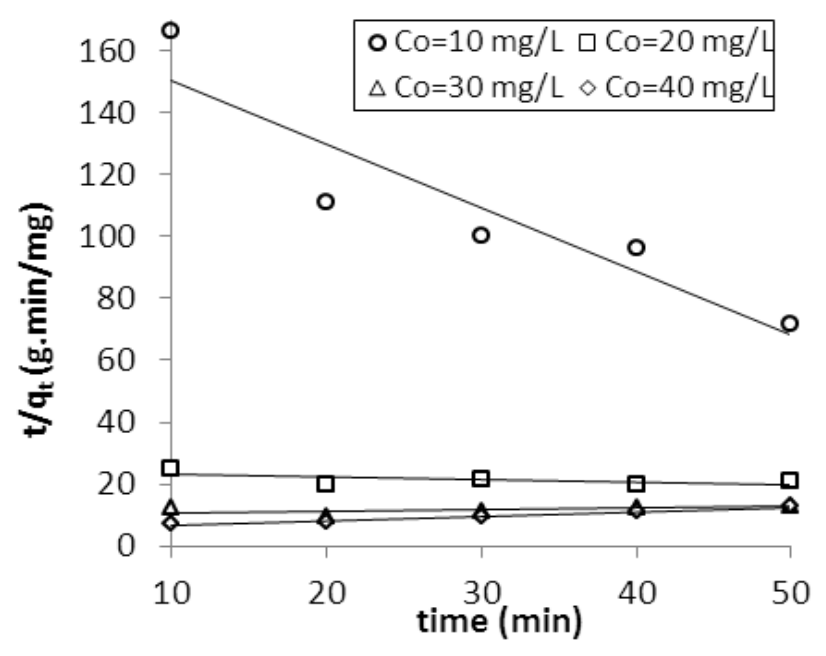

Figure 6. Pseudo second order model results for tartrazine photodegradation by PSA (PSA loading, $5 \mathrm{~g} / \mathrm{L}$; temperature, $25^{\circ} \mathrm{C}$ ).

\section{Intra-Particle Diffusion Model}

The diffusion mechanism of the process was modelled using the intra-particle diffusion model as follows [46]:

$$
q_{t}=K_{p} t^{1 / 2}+C
$$


$K_{p}$ is the intra-particle diffusion rate constant $\left(\mathrm{mg} / \mathrm{g} \cdot \mathrm{min}^{1 / 2}\right)$ and $C$ is a measure of the boundary layer effect. The values of the intra-particle diffusion model parameters at different initial dye concentrations are presented in Table 1 . The plot of $q_{t}$ versus $t^{1 / 2}$ from which the parameters were calculated is shown in Figure 7. The plot indicates the existence (although not significant) of some boundary layer effect and further showed that intra-particle diffusion was not the only rate-limiting step. The high $R^{2}$ values obtained for the kinetic parameters estimated within the concentration range investigated showed that the intra-particle diffusion model was able to describe the diffusion mechanism of the process.

\section{Langmuir-Hinshelwood Model}

The Langmuir-Hinshelwood kinetic model developed by Turchi and Ollis [47] can be expressed as follows:

$$
r_{o}=-\frac{d c}{d t}=\frac{k_{r} K C_{e q}}{1+K C_{e q}}
$$

$r_{o}$ is the initial rate of reaction in $\mathrm{mg} / \mathrm{L} . \mathrm{min}, k_{r}$ is the rate constant for photocatalysis in $\mathrm{mg} / \mathrm{L} . \mathrm{min}, K$ is the rate constant for adsorption in $\mathrm{L} / \mathrm{mg}, C_{\text {eq }}$ is the concentration of bulk solution in $\mathrm{mg} / \mathrm{L}$ at adsorption equilibrium, $c$ is the concentration of bulk solution at any time $t$. Eq. (7) may be expressed in its linearised form as follows:

$$
\frac{1}{r_{o}}=\frac{1}{k_{r} K} \frac{1}{C_{e q}}+\frac{1}{k_{r}}
$$

Values of $1 / r_{\mathrm{o}}$ were plotted against $1 / C_{\mathrm{eq}}$ for the dye as shown in Figure 8 and the values of the calculated constants are presented in Table 1.

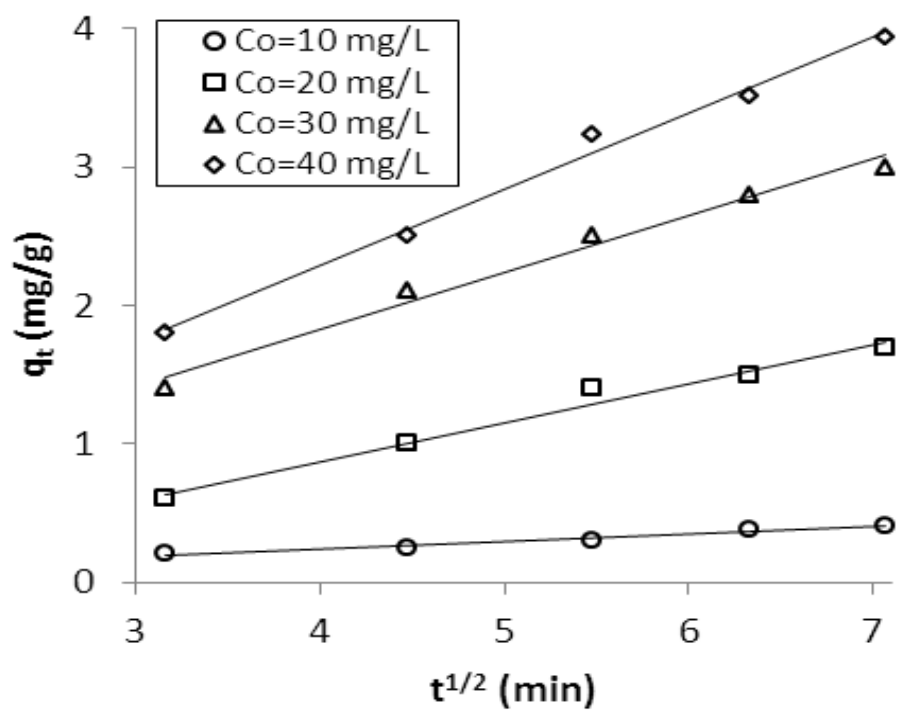

Figure 7. Intra-particle diffusion model results for tartrazine photodegradation by PSA (PSA loading, $5 \mathrm{~g} / \mathrm{L}$; temperature, $25{ }^{\circ} \mathrm{C}$ ). 


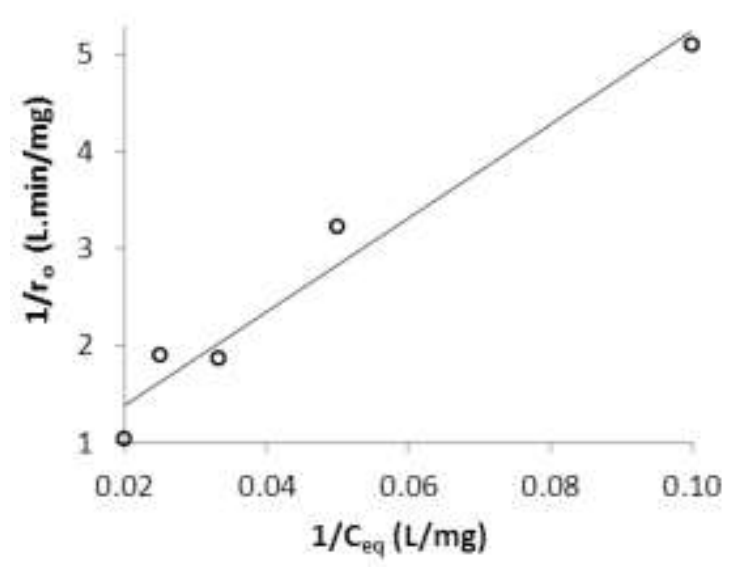

Figure 8. Langmuir-Hinshelwood model results for tartrazine photodegradation by PSA (PSA loading, $5 \mathrm{~g} / \mathrm{L}$; temperature, $25^{\circ} \mathrm{C}$ ).

\section{Adsorption Isotherm Studies}

The Langmuir and Freundlich adsorption isotherm models were used to analyse the equilibrium data for the photocatalytic degradation of tartrazine dye.

\section{Langmuir Isotherm}

The Langmuir isotherm model, which assumes monolayer adsorption of the adsorbate, can be expressed in its linear form as follows [48];

$$
\frac{C_{e}}{q_{e}}=\frac{1}{q_{o}} C_{e}+\frac{1}{K_{L} q_{o}}
$$

$q_{o}$ is the maximum sorption capacity $(\mathrm{mg} / \mathrm{g})$ of the adsorbent while $K_{L}$ is the sorption constant (L/mg). A linear plot of $C_{e} / q_{e}$ against $C_{e}$ as shown in Figure 9 was used to calculate the values of $q_{o}$ and $K_{L}$, which are presented in Table 2 alongside the correlation coefficient $\left(R^{2}\right)$ value.

Table 2. Kinetic parameters for Langmuir and Freundlich isotherms.

\begin{tabular}{llllll}
\hline & Langmuir isotherm & \multicolumn{3}{c}{ Freundlich isotherm } \\
\hline$q_{o}(\mathrm{mg} / \mathrm{g})$ & $K_{L}(\mathrm{~L} / \mathrm{mg})$ & $R^{2}$ & $K_{f}(\mathrm{mg} / \mathrm{g})$ & $\mathrm{N}$ & $R^{2}$ \\
\hline 0.531 & 5.160 & 0.999 & 0.393 & 1.560 & 0.959 \\
\hline
\end{tabular}

The separation factor $\left(R_{L}\right)$ can be used to determine whether or not the adsorption process will be favourable [50]. The parameter predicts that the type of isotherm could be irreversible $\left(R_{L}=0\right)$, favourable $\left(0<R_{L}<1\right)$ or unfavourable $\left(R_{\mathrm{L}}>1\right)$.

$$
R_{L}=\frac{1}{\left(1+K_{L} C_{o}\right)}
$$

$C_{o}$ is the initial concentration of tartrazine. 


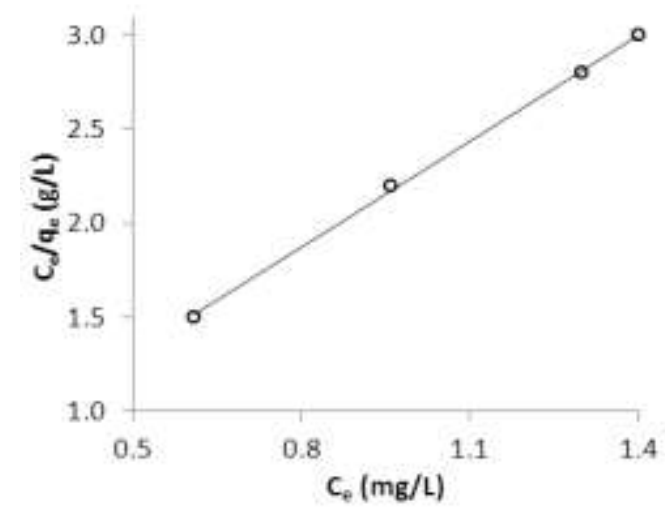

Figure 9. Langmuir isotherm model results for tartrazine photodegradation by PSA

(PSA loading, $5 \mathrm{~g} / \mathrm{L}$; temperature, $25^{\circ} \mathrm{C}$ ).

Table 3. $R_{L}$ values and type of isotherm.

\begin{tabular}{cc}
\hline $\begin{array}{c}\text { Initial concentration } \\
(\mathrm{mg} / \mathrm{L})\end{array}$ & $R_{L}$ Value \\
\hline 10 & 0.019 \\
20 & 0.010 \\
30 & 0.006 \\
40 & 0.009 \\
\hline
\end{tabular}

For this study, the values of $R_{L}$ given in Table 3 are between zero and one, indicating that the adsorption was favourable.

\section{Freundlich Isotherm}

The Freundlich equation is expressed as follows:

$$
q_{e}=K_{f}\left(C_{e}\right)^{1 / n}
$$

Eq. [51] can be expressed in its linearised form as follows:

$$
\ln q_{e}=\ln K_{f}+1 / n \ln C_{e}
$$

$K_{f}$ and $n$ are the Freundlich constants related to the adsorption capacity and adsorption intensity respectively. A linear plot of $\ln q_{e}$ against $\ln C_{e}$ as shown in Figure 10 was employed to calculate the values of the constants. The values of these parameters as well as the correlation coefficient $\left(R^{2}\right)$ of the Freundlich equation are given in Table 2 . The values of $n$ between 1 and 10 typically indicate beneficial and favourable adsorption. Chakrabarti and Dutta [36] reported $K_{f}$ and $n$ values of 0.431 and 1.343 for the photocatalytic degradation of Methylene Blue in wastewater using $\mathrm{ZnO}$ as semiconductor catalyst. Agarry and Aremu [53] suggested that the difference between the values could be a result of differences in the range of concentration, type of material used, $\mathrm{pH}$, temperature and properties of the adsorbent. The high values of the 
correlation coefficients obtained for the Langmuir isotherm as shown in Table 2 indicate that the data conformed well with the Langmuir isotherm equation.

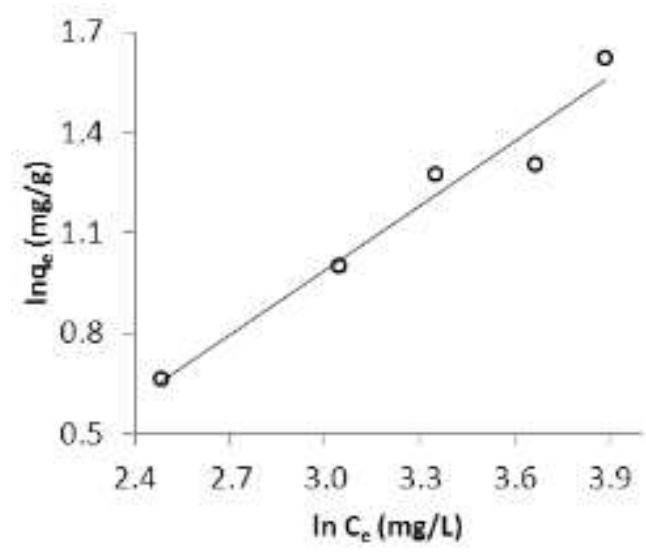

Figure 10. Freundlich isotherm model results for tartrazine photodegradation by PSA (PSA loading, $5 \mathrm{~g} / \mathrm{L}$; temperature, $25^{\circ} \mathrm{C}$ ).

\section{CONCLUSIONS}

Photocatalytic decolourisation of tartrazine was carried out in a continuous flow reactor using periwinkle shell ash as photocatalyst. The decolourisation process was affected by factors such as irradiation time, initial dye concentration and PSA loading dosage. For the conditions considered in this study, the optimum values obtained are as follows: irradiation time, 50 minutes; initial dye concentration, $30 \mathrm{mg} / \mathrm{L}$ and PSA loading, $5 \mathrm{~g} / \mathrm{L}$. The kinetics of the photodegradation of tartrazine was well described by the pseudo first order and the Langmuir-Hinshelwood kinetic models, with high correlation coefficient values $\left(R^{2}>0.9\right)$. The diffusion mechanism and adsorption equilibrium were well described by the intra-particle diffusion model and the Langmuir isotherm equation respectively. PSA has proven to be a suitable alternative to commercially available photocatalysts like $\mathrm{TiO}_{2}$ and $\mathrm{ZnO}$.

\section{ACKNOWLEDGEMENTS}

The author would like to thank University of Benin, Nigeria for providing support and laboratory facilities.

\section{REFERENCES}

[1] Pare B, Jonnalagadda S, Tomar H, Singh P, Bhagwat V. ZnO assisted photocatalytic degradation of acridine orange in aqueous solution using visible irradiation. Desalination. 2008;232:80-90.

[2] Akpan U, Hameed B. Parameters affecting the photocatalytic degradation of dyes using $\mathrm{TiO}_{2}$-based photocatalysts: A review. Journal of Hazardous Materials. 2009;170:520-9.

[3] Sauer T, Cesconeto Neto G, José HJ, Moreira RFPM. Kinetics of photocatalytic degradation of reactive dyes in a $\mathrm{TiO} 2$ slurry reactor. Journal of Photochemistry and Photobiology A: Chemistry. 2002;149:147-54. 
[4] Gao Y, Li C, Yin H, An X, Jin H. Effect of food azo dye tartrazine on learning and memory functions in mice and rats, and the possible mechanisms involved. Journal of Food Science. 2011;76:125-9.

[5] Hannuksela M, Haahtela T. [Food additive hypersenisivity--near myth]. Duodecim; laaketieteellinen aikakauskirja. 2008;125:527-32.

[6] Mehedi N, Mokrane N, Alami O, Ainad-Tabet S, Zaoui C, Kheroua O, et al. A thirteen week ad libitum administration toxicity study of tartrazine in Swiss mice. African Journal of Biotechnology. 2013;12:4519-29.

[7] Mpountoukas P, Pantazaki A, Kostareli E, Christodoulou P, Kareli D, Poliliou S, et al. Cytogenetic evaluation and DNA interaction studies of the food colorants amaranth, erythrosine and tartrazine. Food and Chemical Toxicology. 2010;48:2934-44.

[8] Behnajady M, Modirshahla N, Hamzavi R. Kinetic study on photocatalytic degradation of CI Acid Yellow 23 by $\mathrm{ZnO}$ photocatalyst. Journal of Hazardous Materials. 2006;133:226-32.

[9] Forgacs E, Cserhati T, Oros G. Removal of synthetic dyes from wastewaters: a review. Environment International. 2004;30:953-71.

[10] Bergamini R, Azevedo EB, Araújo LR. Heterogeneous photocatalytic degradation of reactive dyes in aqueous $\mathrm{TiO}_{2}$ suspensions: Decolorization kinetics. Chemical Engineering Journal. 2009;149:215-20.

[11] Chen X, Mao SS. Titanium dioxide nanomaterials: synthesis, properties, modifications, and applications. Chemical Reviews. 2007;107:2891-959.

[12] Felix A, Amenaghawon A, Mededode A. Heterogeneous photocatalytic degradation of naphthalene using periwinkle shell ash: effect of operating variables, kinetic and isotherm study. South African Journal of Chemical Engineering. 2014;19:31-45.

[13] Matilainen A, Sillanpää M. Removal of natural organic matter from drinking water by advanced oxidation processes. Chemosphere. 2010;80:351-65.

[14] Akyol A, Bayramoglu M. The degradation of an azo dye in a batch slurry photocatalytic reactor. Chemical Engineering and Processing: Process Intensification. 2008;47:2150-6.

[15] Inamdar J, Singh S. Photocatalytic detoxification method for zero effluent discharge in dairy industry: Effect of operational parameters. International Journal of Chemical and Biological Engineering. 2008;1:160-4.

[16] RamMohan G, Rosenberger P, Buxy S, Pullammanappallil P, Goswami T. Titanium Dioxide Mediated Photocatalytic Degradation of Methylene Blue in a Fixed Film-Type Photoreactor. AATCC Review. 2014;14:40-4.

[17] Sahel K, Bouhent M, Belkhadem F, Ferchichi M, Dappozze F, Guillard C, et al. Photocatalytic degradation of anionic and cationic dyes over TiO2 P25, and Tipillared clays and Ag-doped Ti-pillared clays. Applied clay science. 2014;95:205-10.

[18] Sakthivel S, Neppolian B, Shankar M, Arabindoo B, Palanichamy M, Murugesan V. Solar photocatalytic degradation of azo dye: comparison of photocatalytic efficiency of $\mathrm{ZnO}$ and $\mathrm{TiO}_{2}$. Solar Energy Materials and Solar Cells. 2003;77:65-82.

[19] Srinivasan A, Viraraghavan T. Decolorization of dye wastewaters by biosorbents: a review. Journal of Environmental Management. 2010;91:1915-29. 
[20] Zanoni MVB, Sene JJ, Anderson MA. Photoelectrocatalytic degradation of Remazol Brilliant Orange 3R on titanium dioxide thin-film electrodes. Journal of Photochemistry and Photobiology A: Chemistry. 2003;157:55-63.

[21] Liu G, Wang Z, Zheng W, Yang S, Sun C. Visible-Light-Driven Photocatalytic Degradation of Aniline over NaBiO 3. Advances in Condensed Matter Physics. 2014;2014:1-5.

[22] Altın İ, Sökmen M. Preparation of TiO2-polystyrene photocatalyst from waste material and its usability for removal of various pollutants. Applied Catalysis B: Environmental. 2014;144:694-701.

[23] da Silva WL, Lansarin MA, Stedile FC, dos Santos JH. The potential of chemical industrial and academic wastes as a source of supported photocatalysts. Journal of Molecular Catalysis A: Chemical. 2014;393:125-33.

[24] Sapiña M, Jimenez-Relinque E, Castellote M. Turning waste into valuable resource: potential of electric arc furnace dust as photocatalytic material. Environmental Science and Pollution Research. 2014;21:12091-8.

[25] Sugrañez R, Cruz-Yusta M, Mármol I, Morales J, Sánchez L. Preparation of sustainable photocatalytic materials through the valorization of industrial wastes. ChemSusChem. 2013;6:2340-7.

[26] Aisien FA, Amenaghawon NA, Ekpenisi EF. Photocatalytic decoloration of industrial wastewater from a soft drink company. Journal of Engineering and Applied Sciences. 2013;9:11-6.

[27] Osarumwense JO, Aisien FA. Application of local pozzolans in the photodegradation of toluene. Nigerian Journal of Biomedical Engineering. 2012;10:13-9.

[28] Aku S, Yawas D, Madakson P, Amaren S. Characterization of periwinkle shell as asbestos-free brake pad materials. Pacific Journal of Science and Technology. 2012;13:57-63.

[29] Navaladian S, Janet C, Viswanathan B, Viswanath R, Kaneco S, Katsumata H. On the possible treatment procedures for organic contaminants. Photo/electrochemistry \& Photobiology in the Environment, Energy and Fuel. 2007:1-51.

[30] Palmisano G, Augugliaro V, Pagliaro M, Palmisano L. Photocatalysis: a promising route for 21 st century organic chemistry. Chemical Communications. 2007:3425-37.

[31] Owabor C, Iyaomolere A. Evaluation of the influence of salt treatment on the structure of pyrolyzed periwinkle shell. Journal of Applied Sciences and Environmental Management. 2013;17:321-7.

[32] Umoh AA, Olusola KO. Compressive strength and static modulus of elasticity of periwinkle shell ash blended cement concrete. International Journal of Sustainable Construction Engineering and Technology. 2012;3:45-55.

[33] Park D, Yun Y-S, Park JM. Studies on hexavalent chromium biosorption by chemically-treated biomass of Ecklonia sp. Chemosphere. 2005;60:1356-64.

[34] Royer B, Cardoso NF, Lima EC, Vaghetti JC, Simon NM, Calvete T, et al. Applications of Brazilian pine-fruit shell in natural and carbonized forms as adsorbents to removal of methylene blue from aqueous solutions-Kinetic and equilibrium study. Journal of Hazardous Materials. 2009;164:1213-22.

[35] Umoren S, Etim U, Israel A. Adsorption of methylene blue from industrial effluent using poly (vinyl alcohol). J Mater Environ Sci. 2013;4:75-86. 
[36] Chakrabarti S, Dutta BK. Photocatalytic degradation of model textile dyes in wastewater using $\mathrm{ZnO}$ as semiconductor catalyst. Journal of Hazardous Materials. 2004;112:269-78.

[37] Akyol A, Yatmaz H, Bayramoglu M. Photocatalytic decolorization of Remazol Red RR in aqueous $\mathrm{ZnO}$ suspensions. Applied Catalysis B: Environmental. 2004;54:19-24.

[38] Konstantinou IK, Albanis TA. TiO2-assisted photocatalytic degradation of azo dyes in aqueous solution: kinetic and mechanistic investigations: A review. Applied Catalysis B: Environmental. 2004;49:1-14.

[39] Daneshvar N, Salari D, Khataee A. Photocatalytic degradation of azo dye acid red 14 in water: investigation of the effect of operational parameters. Journal of Photochemistry and Photobiology A: Chemistry. 2003;157:111-6.

[40] Faramarzpour M, Vossoughi M, Borghei M. Photocatalytic degradation of furfural by titania nanoparticles in a floating-bed photoreactor. Chemical Engineering Journal. 2009;146:79-85.

[41] Shanthi M, Kuzhalosai V. Photocatalytic degradation of an azo dye, Acid Red 27, in aqueous solution using nano $\mathrm{ZnO}$. Indian Journal of Chemistry-Part A InorganicPhysical Theoretical and Analytical. 2012;51:428-34.

[42] So C, Cheng MY, Yu J, Wong P. Degradation of azo dye Procion Red MX-5B by photocatalytic oxidation. Chemosphere. 2002;46:905-12.

[43] Suri RP, Liu J, Hand DW, Crittenden JC, Perram DL, Mullins ME. Heterogeneous photocatalytic oxidation of hazardous organic contaminants in water. Water Environment Research. 1993;65:665-73.

[44] Largergren S. Zur theorie der sogenannten adsorption geloster stoffe. Kungliga Svenska Vetenskapsakademiens. Handlingar. 1898;24:1-39.

[45] Ho Y-S. Review of second-order models for adsorption systems. Journal of Hazardous Materials. 2006;136:681-9.

[46] Weber W, Morris J. Kinetics of adsorption on carbon from solution. J Sanit Eng Div Am Soc Civ Eng. 1963;89:31-60.

[47] Turchi CS, Ollis DF. Photocatalytic degradation of organic water contaminants: mechanisms involving hydroxyl radical attack. Journal of Catalysis. 1990;122:178-92.

[48] Langmuir I. The adsorption of gases on plane surfaces of glass, mica and platinum. Journal of the American Chemical Society. 1918;40:1361-403.

[49] Manning R, Ewing, J. (2009). .RACQ Vehicles Technologies. Temperatures in cars survey. RACQ Vehicles Technologies. 2009:1-21.

[50] Annadurai G, Ling LY, Lee J. Biodegradation of phenol by Pseudomonas pictorum on immobilized with chitin. African Journal of Biotechnology. 2007;6:296-303.

[51] Papuga J. A survey on evaluating the fatigue limit under multiaxial loading. International Journal of Fatigue. 2011;33:153-65.

[52] Wang J, Lu M-X, Zhang L, Chang W, Xu L-N, Hu L-H. Effect of welding process on the microstructure and properties of dissimilar weld joints between low alloy and duplex stainless steel. International Journal of Minerals, Metallurgy and Materials. 2012;19:518-24.

[53] Agarry S, Aremu M. Batch equilibrium and kinetic studies of simultaneous adsorption and biodegradation of phenol by pineapple peels immobilized Pseudomonas aeruginosa NCIB 950. British Biotechnology Journal. 2012;2:2648. 